\title{
Determining of the Convenient Metal Dental Implant Material In Terms of Strength Properties
}

\author{
Ukbe Uçar and Figen Balo* \\ Department of Industrial Engineering, Firat University, Turkey
}

Submission:March 22, 2018; Published:April 04, 2018

*Corresponding author: Figen Balo, Department of Industrial Engineering, Firat University, Turkey, Email: figenbalo@gmail.com

\begin{abstract}
In health care, the contemporary dentistry is starting to utilize, realize, and understand the biotechnology's advantages. For metal dental implants, the material sciences' study along with the material and design concepts' bio-mechanical sciences supports to implant investigation. By using multi-criteria decision making method, the goal of this paper is to choose the most convenient metal dental implant material in human health. Among metal dental implant materials, the problem of choosing the most proper materials is evaluated, using important criteria related properties. In this article, the main properties of diverse metal dental implant materials have been investigated and their material strength properties have been evaluated by experts at medical, dentist and material area.
\end{abstract}

Keywords: Implant; Multi-Criteria Decision Making; Ahp; Strength; Dental

\section{Introduction}

The dental implants' utilize has increased obviously in the recent years, driven by populations' ageing, and the patients' desire to sustain the same activity level and life's quality. For this reason, the requisition for high-effectiveness dental implant materials that can address challenges in spine, vascular therapy, cardiology, orthopedics, trauma, wound and dental maintenance has also been rising continuous. As a dental implant, in an attempt to change missing teeth numerous diverse materials have been tested. In the technology and science with all the developments and advancements, the materials suitable for implants also developed [1]. (Table 1) is displayed to the materials developed as a dental implant [2]. The available biomaterials' functionality and diversity, as well as the techniques for their assembly and processing into implacable apparatus, have also experienced important development, with the hybrid, natural, and synthetic materials' wide variety right now on the market [3-6].This variety allows for material's better choice to fulfill the treatment's specific goals. Lately, there has been an important emphasis on the selected dental implant materials' multi-functionality. (Figure 1) is shown the application of dental implant material [2]. The implant material's right choice is an important factor for implants' long term performance. In terms of strength, this paper determines the most convenient among different metal dental implant materials which were used in the recently.

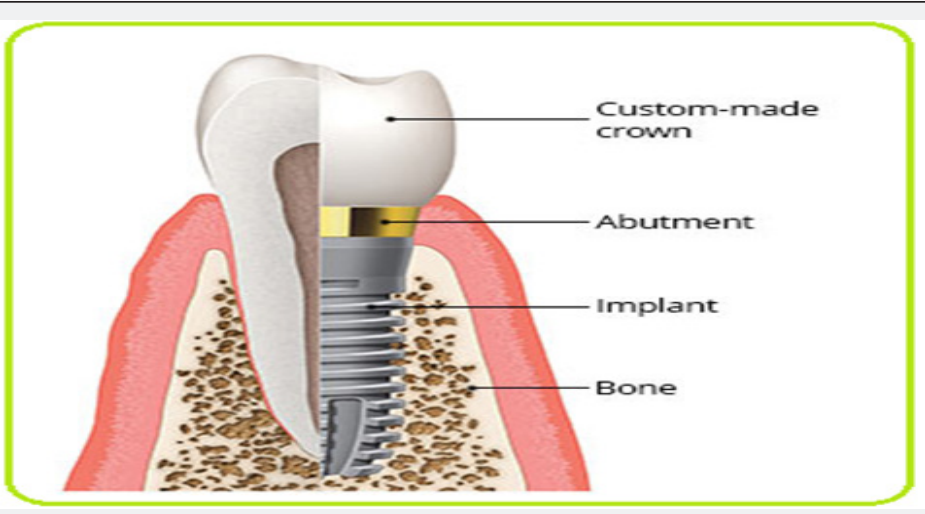

Figure 1: The application of dental implant material. 
Table 1: The materials developed as a dental implant.

\begin{tabular}{|c|c|c|c|}
\hline \multirow{2}{*}{ Biodynamic Activity } & \multicolumn{2}{|c|}{ Chemical Composition } \\
\hline & Metals & Ceramics & Polymers \\
\hline Biotolerant & Gold & & Polyethylene \\
\hline & Co-Cr alloys & & Polyamide \\
\hline & Stainless Steel & & Polyurethane \\
\hline & Niobium & Al oxide & \\
\hline Bio inert & Tantalum & Hydroxyapathethacrylate \\
\hline & Commercially pure titanium & Tricalcium phosphate & \\
\hline Bio active & Titanium alloy (Ti-6AL-4U) & Bio glass & \\
\hline & & Carbon Silicon & \\
\hline
\end{tabular}

\section{Method and Materials}

In this paper, The Analytic Hierarchy Process (AHP) is used. It is developed by Saaty [7]. For dealing with complex decision making, this method is an influential tool and obtains the most accurate decision and may support the decision-maker to determine true priorities. By decreasing decisions complicated to pair wise comparisons' a series, and then synthesizing the conclusions, AHP method aims to obtain both objective and subjective views of the decision. Besides, AHP technique in corporate a utilize method for assessing the decision-makers evaluations' consistency, therefore decreasing the preconception in the decision-making procedure. By using AHP technique, the choice of the best metal dental implant material is obtained in this study. The conclusions are important both from dentist and material science perspective as the implemented method is practically applicable.
Table 2: The proposed decision tree for the problem.

\begin{tabular}{|c|c|c|c|c|}
\hline $\begin{array}{c}\text { Tissue/ } \\
\text { Material }\end{array}$ & $\begin{array}{c}\text { Young's } \\
\text { Modulus } \\
\text { (GPa) }\end{array}$ & $\begin{array}{c}\text { Yield } \\
\text { Strength } \\
\text { (MPa) }\end{array}$ & $\begin{array}{c}\text { Compression } \\
\text { Strength } \\
\text { (MPa) }\end{array}$ & $\begin{array}{c}\text { Tensile } \\
\text { Strength } \\
\text { (MPa) }\end{array}$ \\
\hline $\begin{array}{c}\text { Ti6A14V } \\
\text { (casted) }\end{array}$ & 114 & $760-880$ & 855 & $895-930$ \\
\hline $\begin{array}{c}\text { Ti6A14V } \\
\text { (wrought) }\end{array}$ & 114 & $827-1103$ & $896-1172$ & $860-965$ \\
\hline $\begin{array}{c}\text { Stainless } \\
\text { steel 316L }\end{array}$ & 193 & $170-310$ & $840-620$ & $540-1000$ \\
\hline $\begin{array}{c}\text { CoCrMo } \\
\text { Alloy }\end{array}$ & 240 & $500-1500$ & 452 & $900-1540$ \\
\hline $\begin{array}{c}\text { Mg } \\
\text { (99.9\%, } \\
\text { casted) }\end{array}$ & 41 & 21 & 40 & 87 \\
\hline $\begin{array}{c}\text { Mg(99.9\%, } \\
\text { wrought) }\end{array}$ & 41 & 100 & $100-140$ & 180 \\
\hline
\end{tabular}

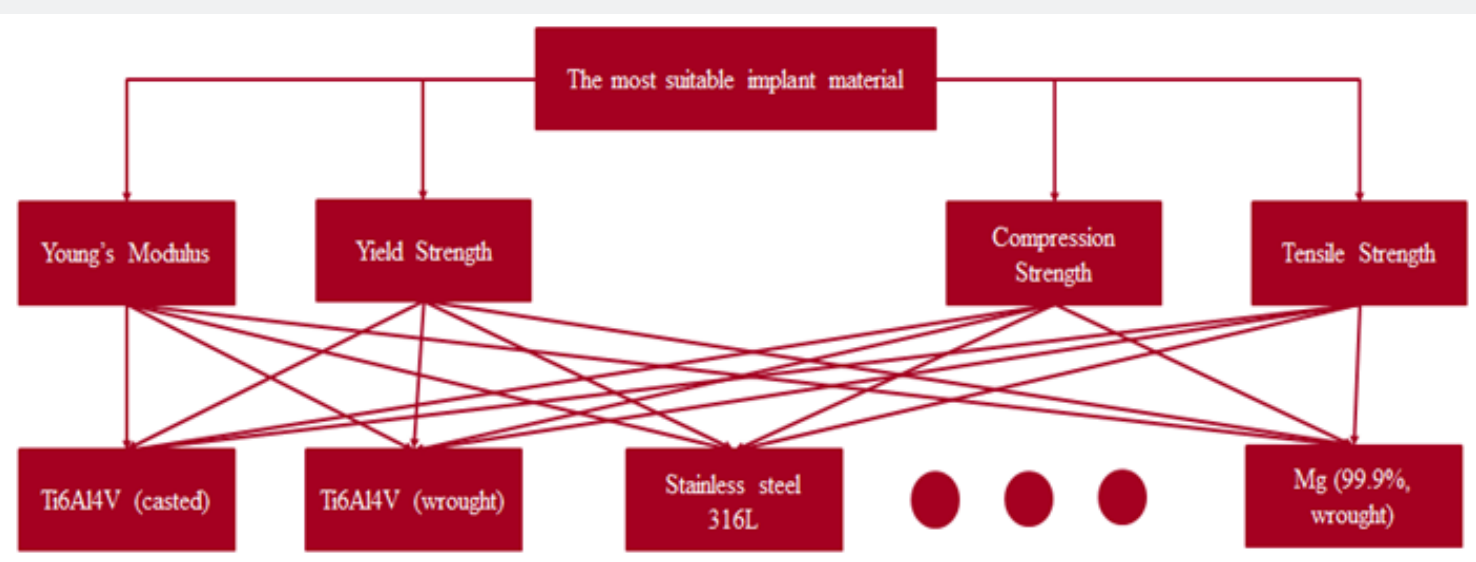

Figure 2: The proposed decision tree for the problem.

In the study, the metal dental implant materials assessed are stated as below.
a) Ti6Al4V (casted)
b) Ti6Al4V (wrought)

c) Stainless steel 316L

d) Co Cr Mo Alloy

e) $\operatorname{Mg}(\% 99,9$, casted $)$

f) $\quad \operatorname{Mg}(\% 99,9$, wrought $)$ 
Four different criteria have been identified for the evaluation of implant materials in the study. These criteria are;

a) Young's Modulus (G Pa)

b) Yield Strength (M Pa)

c) Compression Strength (M Pa)

d) Tensile Strength (M Pa)

Technical properties of implant materials according to the respective criteria are shown in Table 2 (Figure 2) [8].

\section{Conclusion}

In this paper, the AHP method is used to solve the problem and it is benefited from the Expert Choice program. The priority values of the criteria according to the AHP method are presented in (Figure 3). Furthermore, since the consistency of the matrix is 0.02 and this value is smaller than 0.1 , the matrix is consistent. According to (Figure 4), the most important criterion is the compression strength and the least important criterion is the young's modulus and tensile strength. The result obtained from the analysis. According to Table 2 while the most suitable implant material is the $\mathrm{Ti}_{6} \mathrm{Al}_{4} \mathrm{~V}$ (wrought) in terms of mechanical properties, the lowest priority material is the $\mathrm{Mg}$ (\%99, casted). In addition, it is determined that all the matrices in the method are consistent.
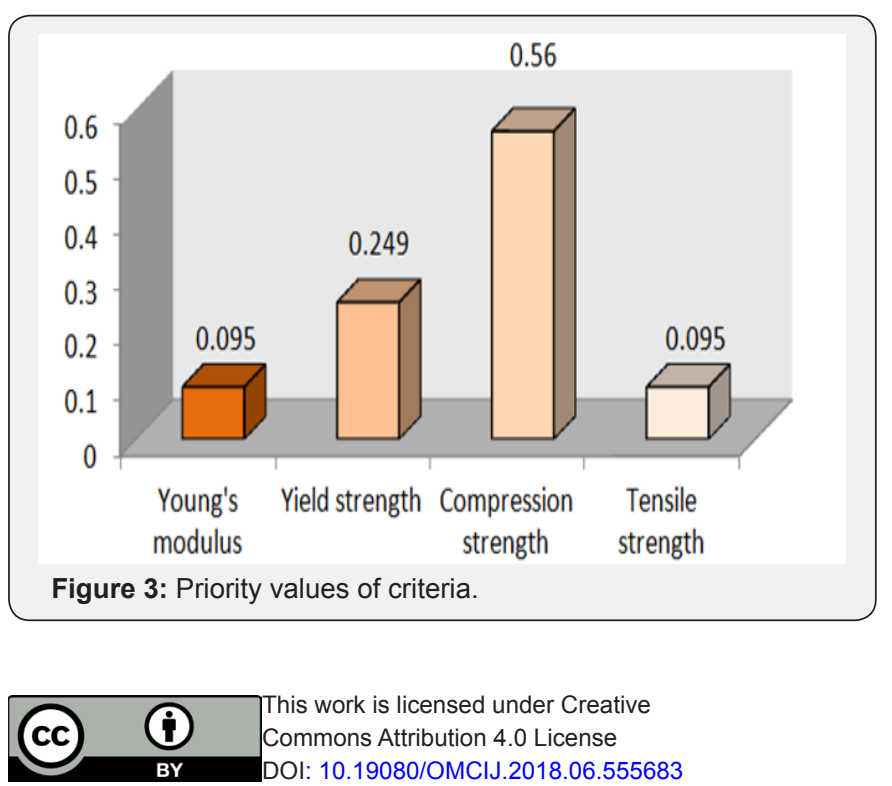

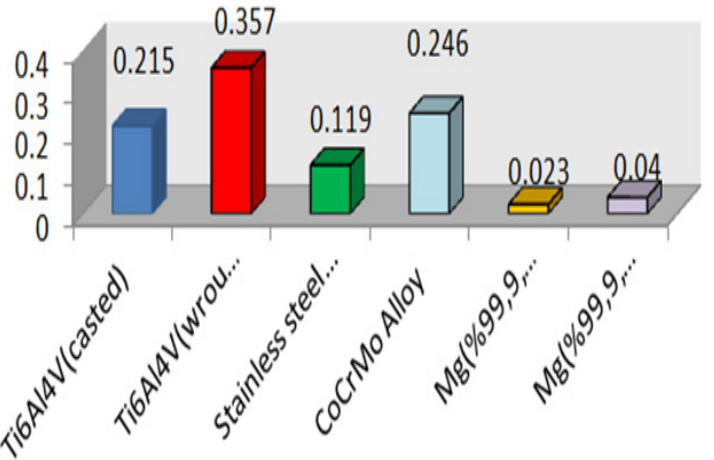

Figure 4: Priority values of implant materials.

\section{References}

1. Hulbert SF, Bennett JT (1975) State of the art in dental implants. J Dent Res 54: 153-157.

2. Monika Saini, Yashpal Singh, Pooja Arora, Vipin Arora, Krati Jain (2015) Implant biomaterials: A comprehensive review. World J Clin Cases 3(1): 52-57.

3. Trivedi P, Nune KC, Misra RDK, Goel S, Jayganthan R, et al. (2016) Grain refine mentto submicron regime in multi axial forged Mg-2Zn-2Gd alloy and relationship to mechanical properties. Mater Sci Eng 668: 59-65.

4. Hong D, Chou DT, Velikokhatnyi OI, Roy A, Lee B (2016) Binder-jetting 3D printing and alloy development of new biodegradable Fe-Mn-Ca/ Mgalloys. Acta Biomater 45: 375-386.

5. Lu JZ, Wu LJ, Sun GF, Luo KY, Zhang YK (2017) Micro structural response and grain refinement mechanism of commercially pure titanium subjected to multiple laser shock peening impacts. Acta Mater 127: $252-266$.

6. Ige 00, Umoru LE, Aribo S (2012) Natural products: A minefield of biomaterials. ISRN Mater Sci p. 20.

7. TL Saaty (1980) The Analytic Hierarchy Process. Mc Graw-Hill, New York.

8. Prasad K, Bazaka O, Chua M, Rochford M, Fedrick L (2017) Metallic biomaterials: Current challenges and opportunities. Materials 10(8): 884. 